\title{
SOCS genes expression during physiological and perturbed implantation in bovine endometrium
}

\author{
A Vitorino Carvalho ${ }^{1}$, P Reinaud ${ }^{1}$, N Forde ${ }^{2}$, G D Healey ${ }^{3}$, C Eozenou ${ }^{1}$, C Giraud-Delville ${ }^{1}$, \\ N Mansouri-Attia ${ }^{1,4}$, L Gall ${ }^{1}$, C Richard ${ }^{1}$, P Lonergan ${ }^{2}$, I M Sheldon ${ }^{3}$, R G Lea ${ }^{5}$ and O Sandra ${ }^{1}$ \\ ${ }^{1}$ INRA, UMR1198 Biologie du Développement et Reproduction, F-78350 Jouy-en-Josas, France, ${ }^{2}$ School of \\ Agriculture and Food Science, University College Dublin, Dublin, Ireland, ${ }^{3}$ Centre for Reproductive Immunology, \\ Institute of Life Science, College of Medicine, Swansea University, Swansea SA28PP, UK, ${ }^{4}$ Department of Pathology \\ and Immunology, Baylor College of Medicine, Houston, Texas, USA and ${ }^{5}$ School of Veterinary Medicine and Science, \\ University of Nottingham, Sutton Bonington Campus, Loughborough LE12 5RD, Leicestershire, UK
}

Correspondence should be addressed to O Sandra; Email: olivier.sandra@jouy.inra.fr

\begin{abstract}
In mammals, suppressor of cytokine signalling (CISH, SOCS1 to SOCS7) factors control signalling pathways involved in the regulation of numerous physiological processes including pregnancy. In order to gain new insights into the biological functions of SOCS in the endometrium, a comprehensive analysis of SOCS gene expression was carried out in bovine caruncular (CAR) and intercaruncular (ICAR) tissues collected i) during the oestrous cycle, ii) at the time of maternal recognition of pregnancy and at implantation in inseminated females, iii) following uterine interferon-tau (IFNT) infusion at day 14 post-oestrus, iv) following a period of controlled intravaginal progesterone release and v) following transfer of embryos by somatic-cell nuclear transfer (SCNT). The regulatory effects of IFNT on in vitro cultured epithelial and stromal cells were also examined. Altogether, our data showed that CISH, SOCS4, SOCS5 and SOCS7 mRNA levels were poorly affected during luteolysis and pregnancy. In contrast, SOCS1, SOCS2, SOCS3 and SOCS6 mRNA levels were strongly up-regulated at implantation (day 20 of pregnancy). Experimental in vitro and in vivo models demonstrated that only $\mathrm{CISH}$, SOCS1, SOCS2 and SOCS3 were IFNT-induced genes. Immunohistochemistry showed an intense SOCS3 and SOCS6 staining in the nucleus of luminal and glandular epithelium and of stromal cells of pregnant endometrium. Finally, SOCS3 expression was significantly increased in SCNT pregnancies in keeping with the altered immune function previously reported in this model of compromised implantation. Collectively, our data suggest that spatio-temporal changes in endometrial SOCS gene expression reflect the acquisition of receptivity, maternal recognition of pregnancy and implantation.
\end{abstract}

\section{Free French abstract}

A French translation of this abstract is freely available at http://www.reproduction-online.org/content/148/6/545/suppl/DC1.

Reproduction (2014) 148 545-557

\section{Introduction}

The in utero development and subsequent birth of a healthy offspring involve a succession of complex biological steps that have to be passed successfully. One major checkpoint is the process of implantation that relies on the coordinated interactions between a developmentally competent conceptus and the endometrium, the receptivity of which is controlled by progesterone $\left(\mathrm{P}_{4}\right)$ in mammals (Wang \& Dey 2006, Spencer et al. 2007). At implantation, endometrial gene expression patterns reflect a combination of several biological processes including the actions of $\mathrm{P}_{4}$, the impact of embryo-secreted factors and cellular interactions between the trophectoderm and the luminal endometrial epithelium. Thus, the biological functions of the endometrium can be subdivided as follows: i) the ability to respond differentially to embryos displaying various potentials to develop to term and ii) the ability to affect the development trajectory of the embryo at the epigenetic level, making this tissue an active and dynamic interface combining biosensor and biodriver properties (Sandra et al. 2011).

In cattle, implantation takes place from 19 to 20 days after oestrus (Guillomot 1995). In this species as in other ruminants, the extra-embryonic tissues first elongate before they attach to the endometrium. In ruminants, endometrial morphology differs from other mammalian species with the presence of caruncular (CAR) and intercaruncular areas (ICAR), both essential for supporting pregnancy. CAR areas are aglandular structures present in the cyclic endometrium, and they fuse with the foetal cotyledons to give rise to placentomes 
(Atkinson et al. 1984). ICAR areas contain endometrial glands whose presence is critical for conceptus elongation (Gray et al. 2001, 2002). Recent high-throughput data have highlighted specific molecular pathways and genes that account for the biological functions related with each endometrial area (Mansouri-Attia et al. 2009a, Walker et al. 2010).

The elongation process of the extra-embryonic tissues is associated with the secretion of IFNT, which is exclusively produced by trophectoderm cells during the peri-attachment period (Roberts 2007, Ealy \& Yang 2009, Bazer et al. 2010). IFNT is considered the major pregnancy recognition signal in ruminants and its biological actions on the endometrium have been widely investigated (Roberts 2007, Spencer et al. 2007, Spencer et al. 2008). The major roles for IFNT include the inhibition of uterine prostaglandin (PG) F2 $\alpha$ secretion, therefore preventing luteolysis, and the modification of the innate immune response (Hansen 2011). In sheep and cattle, IFNT intrauterine infusions, as well as in vitro cultures of endometrial cells incubated with IFNT, have allowed the identification of target genes that cover a wide range of biological processes and underlie the essential functions of this factor in the establishment of pregnancy (Choi et al. 2001, Kim et al. 2003, Gray et al. 2006, Forde et al. 2011a, 2012, Bauersachs et al. 2012, Eozenou et al. 2012, Mansouri-Attia et al. 2012, Oliveira et al. 2012).

Among the signalling cascades contributing to the regulation of endometrial physiology, a number of analyses have highlighted the JAK/STAT transduction pathway (Choi et al. 2001, Catalano et al. 2005, Joyce et al. 2007, Maj \& Chelmonska-Soyta 2007, Spencer et al. 2007). As regulators of the JAK/STAT signalling cascade, the suppressor of cytokine signalling (SOCS) proteins control the amplitude and the duration of this signalling pathway (Rico-Bautista et al. 2006, Yoshimura et al. 2007). The SOCS family includes eight proteins namely the cytokine-inducible Src homology 2 ( $\mathrm{SH} 2)$ domain containing protein $(\mathrm{CISH})$ and SOCS1-7 that share a central $\mathrm{SH} 2$ domain, flanked by a variable $n$-terminal domain and a $c$-terminal SOCS box (Yoshimura et al. 1995, Endo et al. 1997, Naka et al. 1997, Starr et al. 1997, Hilton et al. 1998, Bullock et al. 2007). The SOCS proteins have been shown to inhibit the JAK tyrosine kinase activity, by competing with STAT transcription factors for phosphorylated tyrosine residues on cytokine receptors or by targeting bound signalling proteins for proteasomal degradation (Kile et al. 2002). The most studied members have been CISH, SOCS1 and SOCS3, which are rapidly but transiently induced by numerous local factors and hormones through the JAK/STAT pathway (Fujimoto \& Naka 2003). The members of the SOCS family have been identified in numerous vertebrate and some invertebrate species (DelgadoOrtega et al. 2013) and are involved in the control of many biological processes and physiological functions including pregnancy (Yoshimura et al. 2007, Fitzgerald et al. 2009). In the context of the uterus, SOCS1 and SOCS3 have been shown to contribute to decidualisation and uterine receptivity in the human (Dimitriadis et al. 2006, Aghajanova et al. 2009) and in the sheep, the endometrial expression of CISH, SOCS1, SOCS2 and SOCS3 transcripts has been reported to be affected by the presence of the conceptus (Sandra et al. 2005). Nevertheless, these data are scattered and fail to provide a comprehensive view of how SOCS factors take part in the regulation of endometrial physiology in mammals. The current study was designed to gain new insights into the involvement of the eight members of the SOCS family in the endometrium. Specifically, the main aims were to investigate i) the expression of steady state levels of the SOCS transcripts in cyclic and pregnant endometrial tissues as well as the cellular localisation of SOCS3 and SOCS6 protein, ii) the regulation of SOCS mRNA expression by $\mathrm{P}_{4}$, a steroid hormone critical for the maintenance of pregnancy in mammals, and IFNT, the major signal of pregnancy recognition in ruminants, using in vivo and in vitro experimental models, and iii) the regulation of the SOCS transcripts in an experimental model of compromised implantation based on the inappropriate biological response of the endometrium facing bovine concepti produced by somatic-cell nuclear transfer (SCNT; Mansouri-Attia et al. 2009b).

\section{Materials and methods}

\section{Animals}

Animal care and all experimental procedures were completed in accordance with European Community Directive 86/609/EC, the Animal Research Ethics Committee of University College Dublin and the French Ministry of Agriculture (authorisation B91332). The protocols were registered by the Department of Health and Children (Ireland) or by the Regional Ethical Committee of Animal Experimentation of INRA and AgroParisTech (France, protocol 12-124). In vitro embryo production and embryo transfer protocols were registered by the French Veterinary Services ( ${ }^{\circ}$ FRPB780 and FRTB910).

\section{Experiment 1: regulation of SOCS $m R N A$ expression during maternal recognition of pregnancy}

As previously described (Forde et al. 2011b, Eozenou et al. 2012), synchronised cross-bred beef heifers were artificially inseminated to generate the pregnant group or were left as noninseminated to generate a cyclic group. The cyclic females were slaughtered at day $16(n=5)$ and at day $20(n=6)$ and uteri were immediately retrieved and flushed. A similar procedure was applied to inseminated heifers that were considered as pregnant (day $16, n=4$; day 20,n=5) when the stage of conceptus development was consistent with the day of pregnancy as determined by stereomicroscopy (Degrelle et al. 2005). Based on ovarian morphology (Arosh et al. 2002), all cyclic heifers sampled at day 20 after oestrus presented a 
regressed corpus luteum, whereas cyclic and pregnant heifers sampled at day 16 as well as pregnant heifers sampled at day 20 presented a functional corpus luteum. Endometrial CAR and ICAR areas were dissected separately from the uterine horn ipsilateral to the corpus luteum (Mansouri-Attia et al. 2009a), frozen in liquid nitrogen and then stored at $-80{ }^{\circ} \mathrm{C}$ for further analyses.

\section{Experiment 2: endometrial SOCS $m R N A$ expression at implantation}

Charolais cows were synchronised by the Crestar method (Mansouri-Attia et al. 2009b). As described in Experiment 1, a cyclic group and a pregnant group (confirmed by the presence of a conceptus at the appropriate stage of development) were generated (cyclic: $n=5$, pregnant: $n=6$ ). Upon slaughter at day 20 after oestrus, tissue samples were immediately frozen in liquid nitrogen and stored at $-80{ }^{\circ} \mathrm{C}$ or fixed in $4 \%$ paraformaldehyde (Electron Microscopy Science, Hatfield, PA, USA) in PBS (Euromedex, Souffelweyersheim, France) for further analyses.

\section{Experiment 3: impact of short-term IFNT uterine infusion on endometrial SOCS mRNA expression}

Cyclic Charolais cows were synchronised by the Crestar method (Mansouri-Attia et al. 2009a). At day 14 after oestrus, recombinant ovine IFNT (rolFNT; $200 \mu \mathrm{g} / \mathrm{ml}, 25 \mathrm{ml} / \mathrm{horn}$; Sandra et al. 2005) or control solution (saline buffer) was infused into the uterine lumen, as previously reported (Forde et al. 2011a, 2012, Eozenou et al. 2012). The cows were slaughtered $2 \mathrm{~h}$ after the intra-uterine infusion and the endometrium of five IFNT-infused and five control cows was collected, dissected and stored as described in Experiment 2.

Experiment 4: impact of in vivo $P_{4}$ supplementation on the endometrial expression of SOCS $m R N A$ in cyclic heifers

As previously described (Carter et al. 2008, Forde et al. 2011a, Eozenou et al. 2012), cyclic cross-bred heifers were implanted a $\mathrm{P}_{4}$-releasing intravaginal device containing $1.55 \mathrm{~g}$ of $\mathrm{P}_{4}$ (Ceva Animal Health Ltd., Amersham, UK) on day 3 after oestrus. The females were slaughtered after 2 days (day 5 post-oestrus, normal $\mathrm{P}_{4}, n=4$; high $\mathrm{P}_{4}, n=3$ ) and 13 days (day 16 postoestrus, normal $\mathrm{P}_{4}, n=3$; high $\mathrm{P}_{4}, n=3$ ) of $\mathrm{P}_{4}$ supplementation. The strips of endometrium (containing CAR and ICAR areas) were collected, snap-frozen in liquid nitrogen and then stored at $-80{ }^{\circ} \mathrm{C}$ for further analyses.

\section{Experiment 5: impact of bovine SCNT concepti on} the endometrial SOCS expression

The cyclic Holstein heifers were synchronised using the Crestar method. As previously described (Mansouri-Attia et al. 2009b), heifers were separated in two experimental groups generated by artificial insemination (pregnant control group) or by transfer of SCNT embryos (two embryos into the ipsilateral horn to the corpus luteum). SCNT embryos produced with an adult donor cell line derived from a Holstein heifer (reference 5538; Degrelle et al. 2012). Upon slaughtering at day 20 post-oestrus, uteri were collected, concepti were recovered by uterine flushing and the correct stage of development was confirmed by microscopy (Degrelle et al. 2005). Only females with a pregnancy confirmed by the presence of an appropriately developed conceptus were analysed (artificially inseminated, $n=4$; SCNT, $n=4$ ). CAR and ICAR endometrial areas were dissected and stored as described for Experiment 2.

\section{Primary cultures of endometrial cells}

Epithelial and stromal cells were isolated from bovine endometrium collected from mixed breed beef cows on day 11-17 of the oestrous cycle, as previously described (Cronin et al. 2012). The cells were treated with control medium (RPMI-1640 medium (Sigma-Aldrich), 10\% heat-inactivated foetal bovine serum (Sigma-Aldrich), 1\% penicillin-streptomycin (Sigma-Aldrich), 1\% amphotericin B (Sigma-Aldrich)) or a medium containing rolFNT $(100 \mathrm{ng} / \mathrm{ml})$ for $2 \mathrm{~h}$ (MansouriAttia et al. 2009a). Each experiment was carried out using isolated cells from four independent animals.

\section{Immunohistochemistry}

The endomerial samples were fixed in $4 \%$ paraformaldehyde in PBS, as previously described (Eozenou et al. 2012). After three washes with PBS, the samples were dehydrated by treating with increasing concentrations of ethanol $(30 \%, 50 \%, 70 \%, 90 \%$, $100 \%$ ) in a Shandon Citadel 1000 tissue processor (Thermo Scientific, Courtaboeuf, France) for $12 \mathrm{~h}$. The tissues were embedded in paraffin and stored at $4{ }^{\circ} \mathrm{C}$ until further processing.

The sections $(7 \mu \mathrm{m})$ were cut with a microtome Leica RM2245 (Leica, Nanterre, France) for immunohistochemistry as previously described (Eozenou et al. 2012). The slides were incubated with primary antibodies, anti-SOCS3 (dilution 1:200, sc9323, Santa Cruz Biotechnology) and anti-SOCS6 (dilution 1:200, ab53181, Abcam, Paris, France), in phosphate buffer $(0.1 \mathrm{M}, \mathrm{pH} 7.4$, with $2 \%$ BSA (Sigma-Aldrich) and $1 \%$ normal donkey serum (Millipore, Guyancourt, France)) at $4{ }^{\circ} \mathrm{C}$ overnight. As negative controls, the sections were incubated in phosphate buffer without primary antibody. The slides were incubated with an anti-rabbit secondary antibody (dilution 1:40; sc-346, Santa Cruz Biotechnology) for $1 \mathrm{~h}$ at room temperature and then washed three times and incubated with diaminobenzidine substrate and urea (Sigmafast 3,3'-diaminobenzidine tablets, Sigma-Aldrich) in Tris-buffer for 6-8 min until colour developed. After one wash in water, the slides were dehydrated through ascending concentrations of ethanol and then mounted with Eukitt mounting medium (Sigma-Aldrich). A section from each physiological condition was stained with haematoxylin-eosin solution to highlight tissue morphology. The images were obtained using a NanoZoomer digital pathology system and analysed using a NanoZoomer digital pathology virtual slide viewer (NDPView software, Hamamatsu, Japan). Each experiment was repeated for four females per biological condition. Four fields per animal were analysed. To evaluate protein expression, three independent observers analysed obtained images and determined protein intensity in each sub-cellular population of endometrium. 


\section{Total RNA extraction}

Total RNA was extracted from frozen tissue by homogenisation in Trizol Reagent (Invitrogen) according to the manufacturer's recommendations and as previously published (Mansouri-Attia et al. 2009a, Eozenou et al. 2012). Total RNA samples were purified on Qiagen columns according to the manufacturer's protocol (RNeasy Mini Kit, Qiagen). The cultured primary cells were washed with $1 \mathrm{ml}$ of PBS and then total RNA was extracted using the RNeasy Mini Kit and the automated system Qiacube (Qiagen; Cronin et al. 2012). Quality and integrity of extracted and purified total RNA were determined using an Agilent 2100 bioanalyser (Agilent, Les Ulis, France). $1 \mu \mathrm{l}$ of RNase inhibitor (RNAsin, Promega) was added to each sample before storing at $-80^{\circ} \mathrm{C}$.

\section{Quantitative real-time PCR}

As previously described (Mansouri-Attia et al. 2009a, Eozenou et al. 2012), $1 \mu \mathrm{g}$ of total RNA was reverse-transcribed into cDNA using OligodT and SuperScript II (Invitrogen). Quantitative real-time PCR (qPCR) was carried out with Master Mix SYBR Green (Applied Biosystems) and Step One Plus system (Applied Biosystems). The primers were designed using PrimerBLAST (NCBI, http://www.ncbi.nlm.nih.gov/tools/primer-blast/ index.cgi?LINK_LOC=BlastHome) or Primer Express Software (Applied Biosystems) and then synthesised by Eurogentec (Angers, France). The oligonucleotide primers used for gene quantification are listed in Table 1. To assess the amplification of the correct cDNA fragments, every amplicon was sequenced and blasted on NCBI RNA bovine collection. For each gene of interest, relative expression was normalised to the expression of the most stable reference genes as determined by qBaseplus software from the quantification of six housekeeping genes (Biogazelle, Ghent, Belgium).

\section{Statistical analyses}

All statistical analyses were performed with GraphPad Prism 6 software (La Jolla, CA, USA). SOCS gene expression in tissues was first subjected to a two-way ANOVA followed by Student's $t$-test tests to analyse the effect of day, pregnancy status (cyclic or pregnant), endometrial areas (CAR and ICAR), and their interactions. SOCS expression in primary cell cultures treated by rolFNT was subjected to a two-way ANOVA analysis followed by Student's $t$-test tests to study the potential differential SOCS expression relative to cell lines and to rolFNT treatment.

\section{Results}

\section{Endometrial SOCS expression during the oestrous cycle and pre-implantation period}

Using bovine endometrium collected from cross-bred beef heifers, SOCS mRNA levels were analysed in the CAR and ICAR endometrial areas at day 16 and day 20 of the oestrous cycle and pregnancy. In cycling heifers, the presence of a regressed or a $\mathrm{P}_{4}$-secreting functional corpus luteum was confirmed by the transcriptional level of FOXL2, a transcription factor whose endometrial mRNA expression is inversely correlated with $\mathrm{P}_{4}$ circulating level (Eozenou et al. 2012).

From day 16 to day 20 post-oestrus (Fig. 1), no significant difference in $\mathrm{CISH}$, SOCS4 and SOCS7 mRNA levels was observed in the endometrium sampled from cyclic heifers, whereas SOCS3 mRNA level increased in CAR and ICAR areas; SOCS5 and SOCS6 gene expression decreased in both endometrial areas and SOCS1 and SOCS2 gene expression increased in ICAR areas only.

In the pregnant endometrium (Fig. 1), no significant variation in CISH, SOCS2, SOCS5 and SOCS7 mRNA expression was seen in either endometrial area between the stage of maternal pregnancy recognition (day 16) and implantation (day 20). At the same period, a significant increase was detected for SOCS4 transcript in the CAR areas and for SOCS1, SOCS3 and SOCS6 transcripts in CAR and ICAR areas.

When pregnant endometrium was compared with cyclic endometrium (Fig. 1 and Table 2), distinct patterns of SOCS mRNA regulation were observed, ranging from the absence of significant change $(\mathrm{CISH}$, SOCS7) to a significant up-regulation of mRNA level in CAR and ICAR areas at day 16 and day 20 (SOCS6).

Table 1 Description of the oligonucleotide primers used for bovine gene quantification by real-time RT-PCR.

\begin{tabular}{|c|c|c|c|c|}
\hline Gene & Forward & Reverse & $\begin{array}{c}\text { Amplicon } \\
\text { size }\end{array}$ & Accession number \\
\hline $\mathrm{CISH}$ & AGTCATCCTGGTGCCCGTGA & AGCCTTGTTCCTGCACACCG & 69 & NM_001046586 \\
\hline SOCS1 & СТСGTAССТССТАССТСТTСАТGTT & ACAGCAGAAAAATAAAGCCAGAGA & 92 & XM_864316 \\
\hline SOCS2 & TGCAAGGATAAGCGGACAGG & AGATGCTGCAGAGGTGGTGCT & 101 & NM_177523 \\
\hline SOCS3 & GССАСТСТССААСАТСТСТGT & TCCAGGAACTCCCGAATGG & 97 & NM_174466 \\
\hline SOCS4 & GCTTTGTTAACCTATGTCATTGGCA & ACAACACACACAGCTTTACCGAAG & 100 & NM_001076218 \\
\hline SOCS5 & TACATCCCAGTGGCTGTCGC & GCACAGCAAGCAGAAACATACATT & 100 & NM_001046182 \\
\hline SOCS6 & AGAAGGTCAAAAAATGTCACAGGAA & CAATGGTTTAGCCTTTTGGCAT & 113 & XM_005224062 \\
\hline SOCS7 & СТСССАСТGССТААGССТСТG & GAAATGAGCTGCGСTTCСTT & 102 & NM_001206013 \\
\hline$A C T B$ & CCTGGCACCCAGCACAA & AGCGAGGCCAGGATGGA & 90 & NM_173979 \\
\hline CNOT11 (C2ORF29) & ССТTCAAGAGСССССТGT & GGGTCСTTTTCCAАСТСТСС & 64 & XM_002691150 \\
\hline GAPDH & GCTGACGCTCCCATGTTTGT & TCATAAGTCCСТCСACGATGC & 432 & NM_001034034 \\
\hline RPL19 & ССССАATGAGACCAATGAAATC & CAGCCСАTСTTTGATCAGCTT & 72 & NM_001040516 \\
\hline SLC30A6 & TGATGAGGAAACCTAGCССТGCC & TCGGGCTGCTCCAAAAAGCGT & 142 & NM_001075766 \\
\hline SUZ12 & CGTTGTGAGCAGTTTTGCССTGT & ACCACAGTGCTTGGAGTTGGACT & 139 & NM_001205587 \\
\hline
\end{tabular}



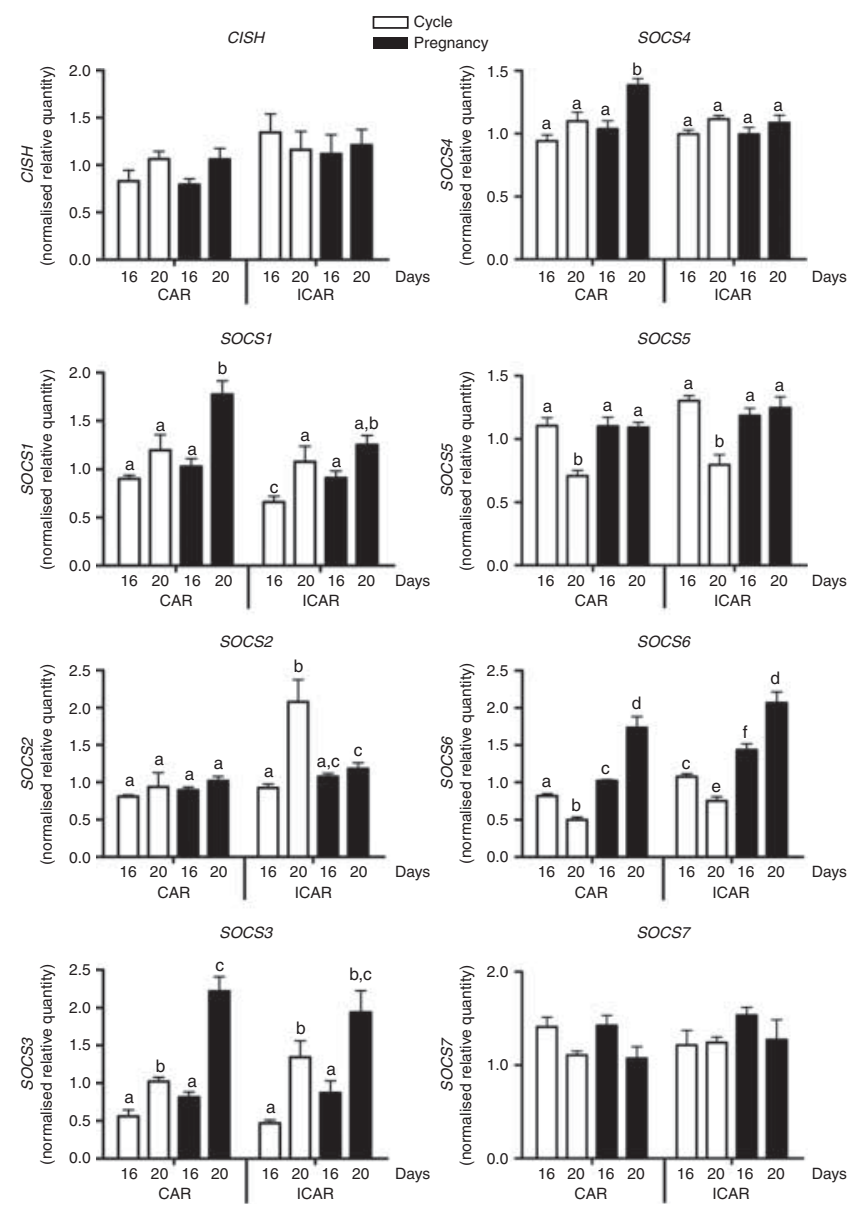

Figure 1 Quantification of SOCS gene expression in cyclic and pregnant bovine endometrium on day 16 and 20 of the oestrous/ pregnancy. Caruncular (CAR) and intercaruncular (ICAR) areas were collected from cyclic (day 16: $n=5$; day 20,n=6) and pregnant (day 16: $n=4$; day 20: $n=5$ ) cross-bred heifers. Expression of SOCS was normalised to that of RPL19 and SCL3OA6 using qBasePlus. Scale Bars (mean \pm s.E.M.) with different lowercase letters differ significantly $(P<0.05$ or lower).

\section{Regulation of endometrial SOCS expression by IFNT}

In order to determine the short-term impact of IFNT on SOCS gene expression, Charolais cows were infused with rolFNT for $2 \mathrm{~h}$ at day 14 of the oestrous cycle (Fig. 2). The primary cultures of endometrial cells (epithelial or stromal origin) were also derived and incubated with rolFNT for $2 \mathrm{~h}$ (Fig. 3). In these experimental models, no impact of IFNT on SOCS4, SOCS5, SOCS6 and SOCS7 transcript levels was seen in vivo or in vitro (Figs 2 and 3).

Intrauterine infusions with rolFNT significantly increased the expression of SOCS1 (4.4-fold in CAR; 6.8-fold in ICAR), SOCS2 (1.8-fold in CAR; 2.8-fold in ICAR) and SOCS3 (fourfold in CAR) mRNA levels (Fig. 2). The expression of $\mathrm{CISH}$ mRNA was also up-regulated by rolFNT treatment when CAR and ICAR endometrial areas were considered together.
In primary cultures of endometrial cells (Fig. 3), CISH and SOCS1 mRNA levels were significantly up-regulated by rolFNT in stromal cells (three- and 8.3 -fold respectively), whereas SOCS1 and SOCS3 mRNA levels were significantly up-regulated by roIFNT in epithelial cells (ten- and 2.3-fold respectively). No significant regulation of SOCS2 transcript expression by IFNT was observed in either cell types. Interestingly, mRNA expression levels of CISH and SOCS4 were lower and those of SOCS1 and SOCS2 were higher in the primary cultures of stromal cells compared with epithelial cells (Fig. 3).

\section{Regulation of endometrial SOCS expression by exogenous $\boldsymbol{P}_{\mathbf{4}}$}

In order to investigate the impact of $\mathrm{P}_{4}$ on SOCS mRNA expression, cross-bred beef heifers were supplemented with $\mathrm{P}_{4}$ from day 3 of the oestrous cycle onwards and the endometrium was sampled at day 5 or day 16 (Fig. 4). A significant increase in mRNA levels was seen for SOCS6 $(P<0.05)$ and SOCS7 $(P<0.01)$ in the $\mathrm{P}_{4}$-treated group (day 5 and day 16) compared with the group of control heifers. SOCS5 gene expression was significantly up-regulated by 13 days of $\mathrm{P}_{4}$ treatment (2.8-fold, $P<0.01)$. No significant impact of $\mathrm{P}_{4}$ was observed for CISH, SOCS1 and SOCS2 transcripts. Interestingly, for $\mathrm{CISH}$ only, this experiment showed an increased expression in endometrial mRNA level from day 5 to day 16 of the oestrous cycle (Fig. 4; $P<0.05$ ). No significant correlation was found between $\mathrm{P}_{4}$ blood concentration and any of the SOCS transcript expression in the endometrium (data not shown).

\section{Immunolocalisation of SOCS3 and SOCS6 in bovine endometrium}

SOCS3 and SOCS6 were localised in endometrial tissues sampled from cyclic Charolais cows on day 14 (luteal phase) and day 20 (follicular phase) as well as in pregnant cows at the time of initiation of implantation (Fig. 5, day 20). During the oestrous cycle, SOCS3 and SOCS6 were detected in luminal, stromal and glandular cells.

Table 2 Effect of pregnancy on bovine SOCS genes expression (fold changes) in caruncular (CAR) and intercaruncular (ICAR) areas at day 16 (D16) and day 20 (D20) after oestrus.

\begin{tabular}{lllllll}
\hline & \multicolumn{3}{c}{ CAR } & & \multicolumn{2}{c}{ ICAR } \\
\cline { 2 - 3 } \cline { 6 - 7 } & $\mathrm{D} 16$ & $\mathrm{D} 20$ & & $\mathrm{D} 16$ & $\mathrm{D} 20$ \\
\hline CISH & 0.96 & 0.99 & & 0.83 & 1.04 \\
SOCS1 & 0.93 & $1.48^{+}$ & & $1.38^{*}$ & 1.16 \\
SOCS2 & 1.11 & 1.09 & & 1.16 & $0.56^{+}$ \\
SOCS3 & $1.45^{*}$ & $2.17^{\S}$ & & $1.85^{*}$ & 1.44 \\
SOCS4 & 1.10 & $1.26^{+}$ & & 0.99 & 0.97 \\
SOCS5 & 0.99 & $1.54^{+}$ & & 0.91 & $1.57^{+}$ \\
SOCS6 & $1.25^{\ddagger}$ & $3.47^{\S}$ & & $1.33^{+}$ & $2.74^{\S}$ \\
SOCS7 & 1.01 & 0.97 & & 1.26 & 1.03 \\
\hline
\end{tabular}

${ }^{*} P<0.05 ;{ }^{\dagger} P<0.01 ;{ }^{\ddagger} P<0.001 ;{ }^{\S} P<0.0001$. 

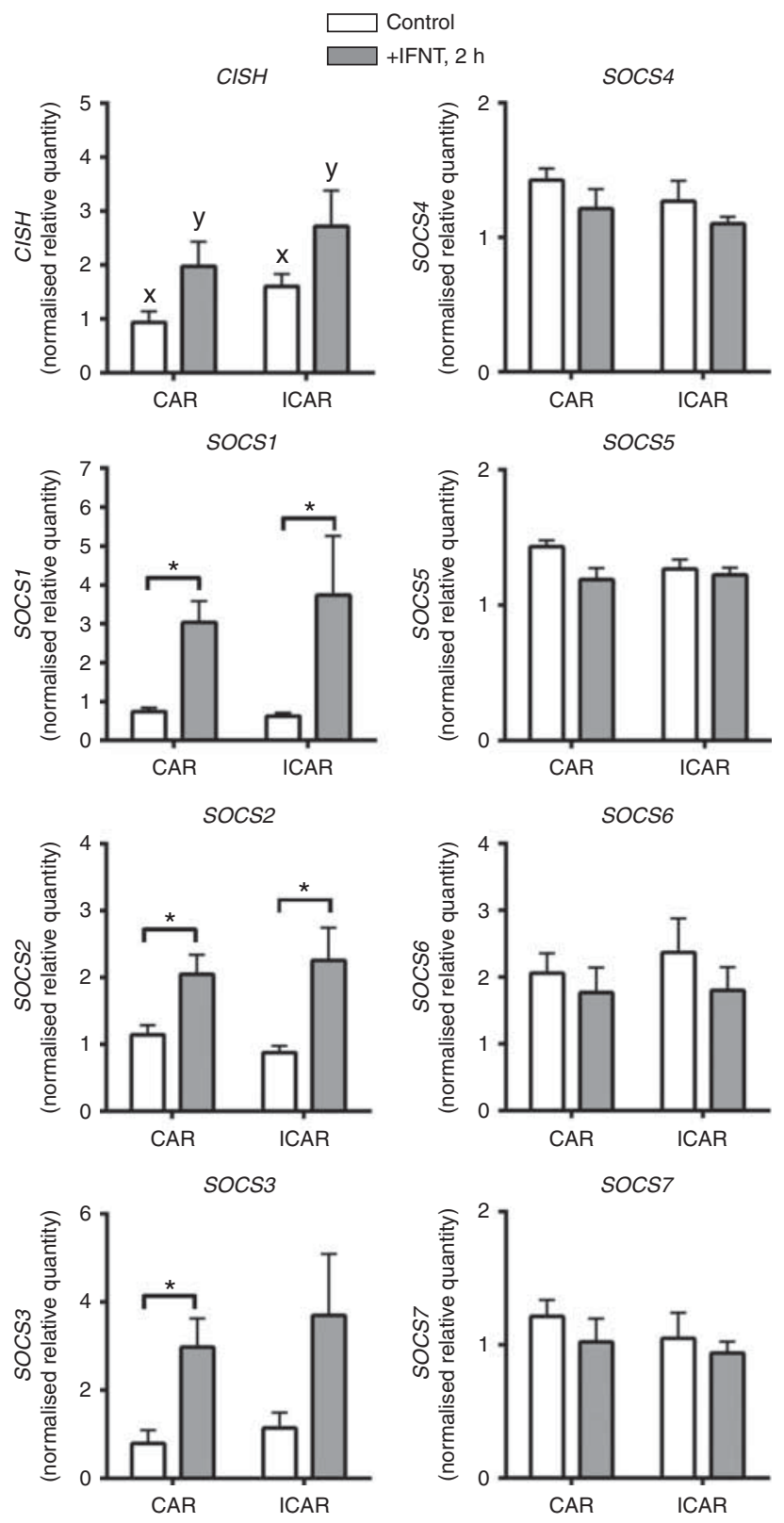

Figure 2 Regulation of endometrial SOCS gene expression by IFNT in vivo. Caruncular (CAR) and intercaruncular (ICAR) endometrial areas were collected from Charolais cows infused with control solution $(n=5)$ or rolFNT $(200 \mu \mathrm{g} / \mathrm{ml} ; n=5)$ for $2 \mathrm{~h}$ at day 14 of oestrous cycle. SOCS mRNA levels were quantified by RT-qPCR and normalised to CNOT11, SLC3OA6 and SUZ12 using qBasePlus. Data are the mean \pm S.E.M.. $\mathrm{x}$ and $\mathrm{y}$ letters indicate significant differences in total endometrial expression between control and IFNT samples $(P<0.05)$. Asterisks denote significant effects $\left({ }^{*} P<0.05\right)$.

Compared with cyclic endometrium (day 14 or day 20), nuclear SOCS3 staining in pregnant endometrium appeared with the same intensity in stromal cells and luminal epithelium, but more intense in glandular cells (Table 3). In luminal, glandular and stromal cells, nuclear SOCS6 staining was less intense in the late-luteal phase (day 20) compared with the mid-luteal phase (day 14).
In luminal cells, SOCS6 staining intensity increased at day 20 of pregnancy (when implantation takes place) compared with either day of the oestrous cycle.

\section{Regulation of endometrial SOCS genes by SCNT concepti}

The endometrium has been shown to distinguish concepti displaying distinct potencies of development
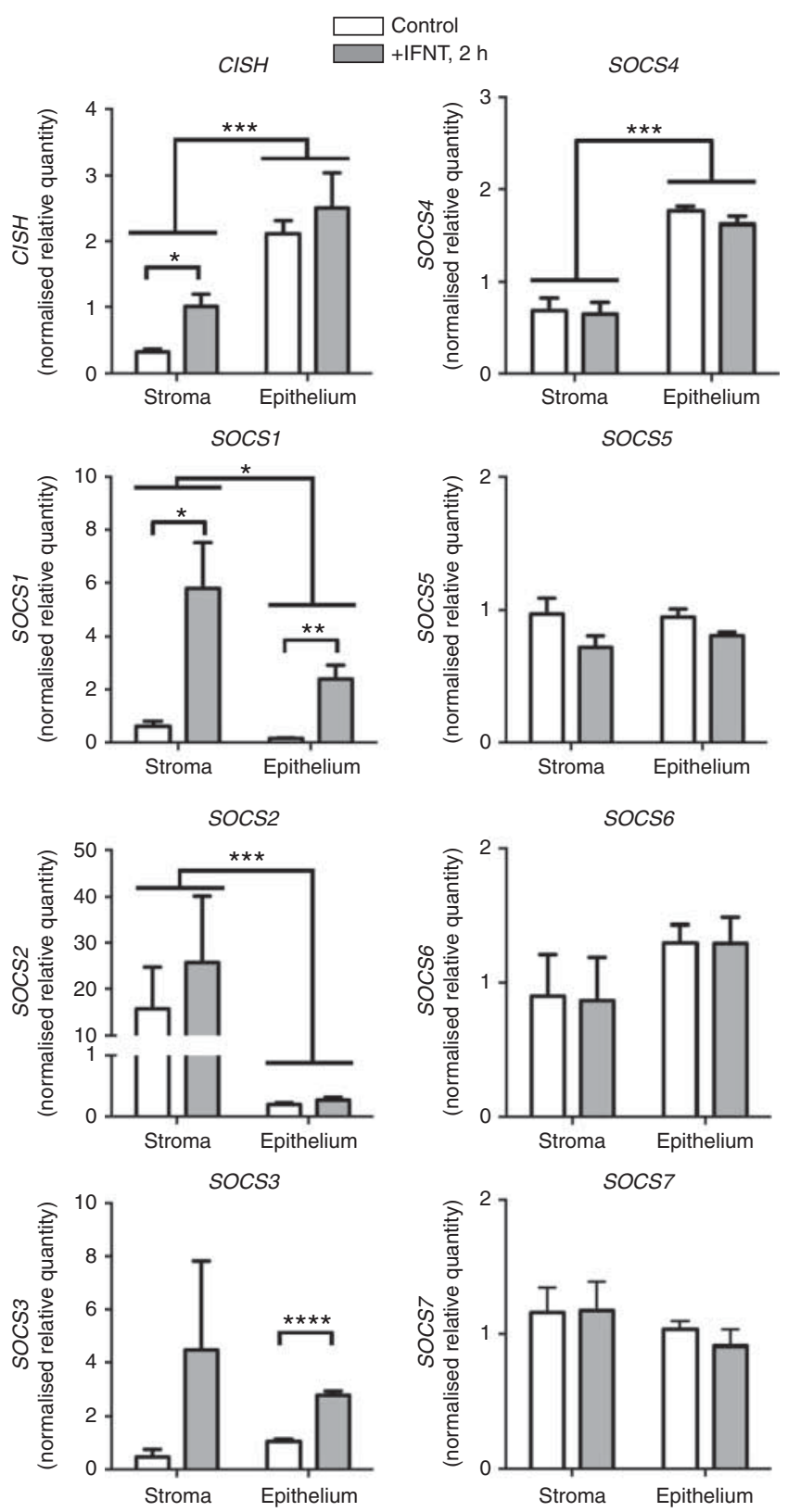

Figure 3 Regulation of SOCS gene expression by IFNT in bovine endometrial cells. In vitro, cells isolated from bovine endometrium were treated with rolFNT $(100 \mathrm{ng} / \mathrm{ml})$ for $2 \mathrm{~h}$. For each gene, mRNA expression was normalised to that of RPL 19 and ACTB using qBasePlus. Data are the mean \pm s.E.M. Asterisks denote significant effects $\left({ }^{*} P<0.05\right.$; ** $P<0.01$; *** $P<0.001$; **** $\left.P<0.0001\right)$. 

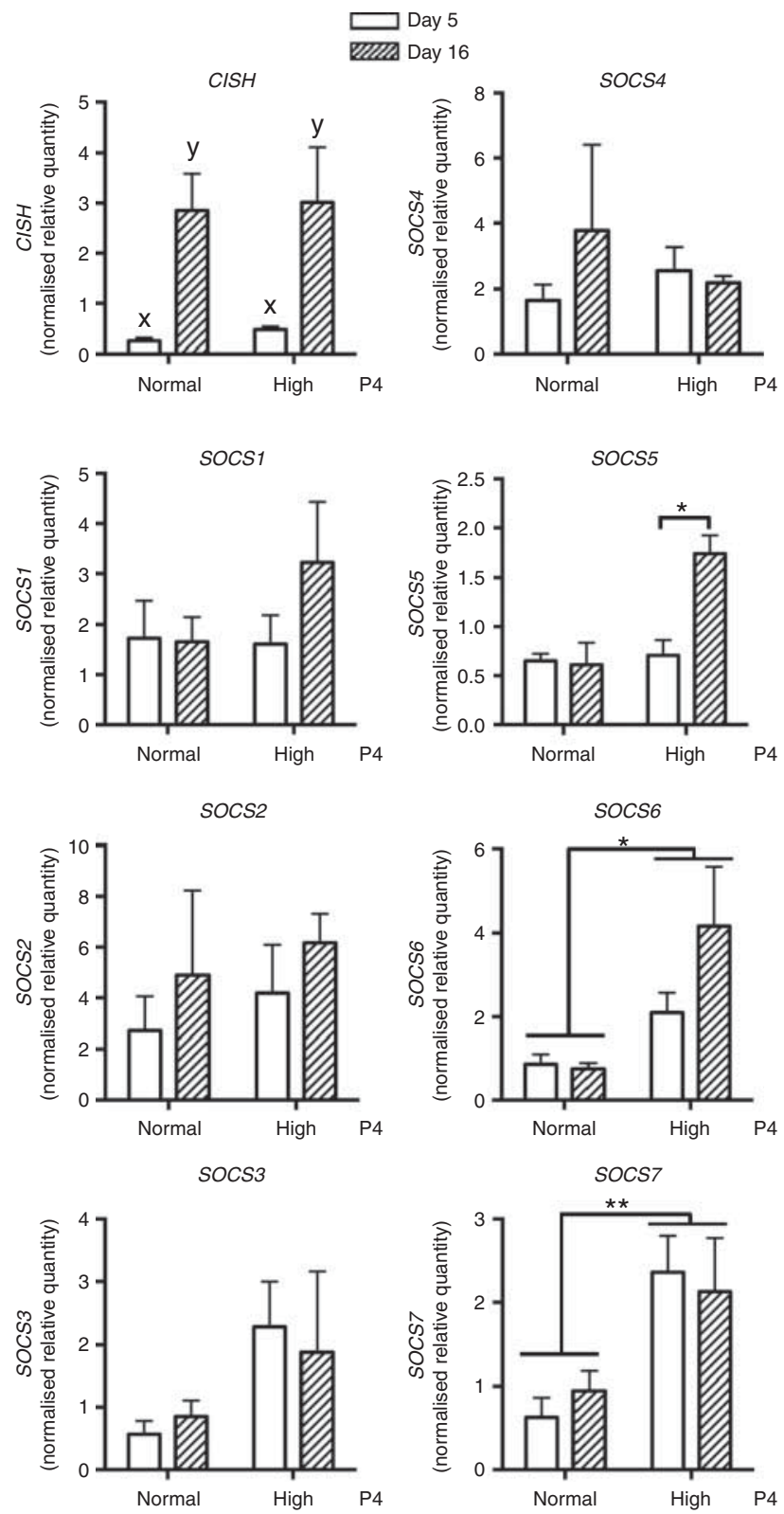

Figure 4 SOCS endometrial gene expression in cyclic and pregnant cross-bred beef heifers supplemented with $\mathrm{P}_{4}$ from day 3 after oestrus. The females were slaughtered after 2 days (day 5 after oestrus, normal $\mathrm{P}_{4}$ level in cyclic heifers, $n=5$ and high $\mathrm{P}_{4}$ level in cyclic heifers, $n=5$ ) and 13 days (day 16 after oestrus, normal $\mathrm{P}_{4}$ level in cyclic heifers, $n=4$ and high $\mathrm{P}_{4}$ level in cyclic heifers, $n=5$ ) of $\mathrm{P}_{4}$ supplementation. SOCS mRNA level was quantified by RT-qPCR and normalised to ACTB and $R P L 19$ using qBasePlus. Scale Bars (mean \pm s.E.M.) represent the different conditions. Asterisks denote significant effects $\left({ }^{*} P<0.05\right.$, **: $P<0.01) \mathrm{x}$ and $\mathrm{y}$ letters indicate significant difference between day 5 and day 16 samples $(P<0.05)$.

to term (Mansouri-Attia et al. 2009b). We investigated the expression of endometrial SOCS genes in day 20 pregnant heifers carrying SCNT concepti compared with control pregnancies. SOCS3 mRNA was significantly increased in the endometrium of SCNT pregnancies
(Fig. 6; $P<0.05$ ) whereas other SOCS genes did not present any significant variation in mRNA concentration.

\section{Discussion}

The family of SOCS proteins has been shown to play essential functions in the negative regulation of cell signalling pathways activated by cytokine and hormone receptors, most of them being expressed at the embryomaternal interface in mammals (Krebs \& Hilton 2001, Fitzgerald et al. 2009). The endometrium is critical for supporting implantation and this depends on its physiological status as well as the developmental potency and quality of the embryo with which it interacts (Salamonsen et al. 2009, Sandra et al. 2011, Weimar

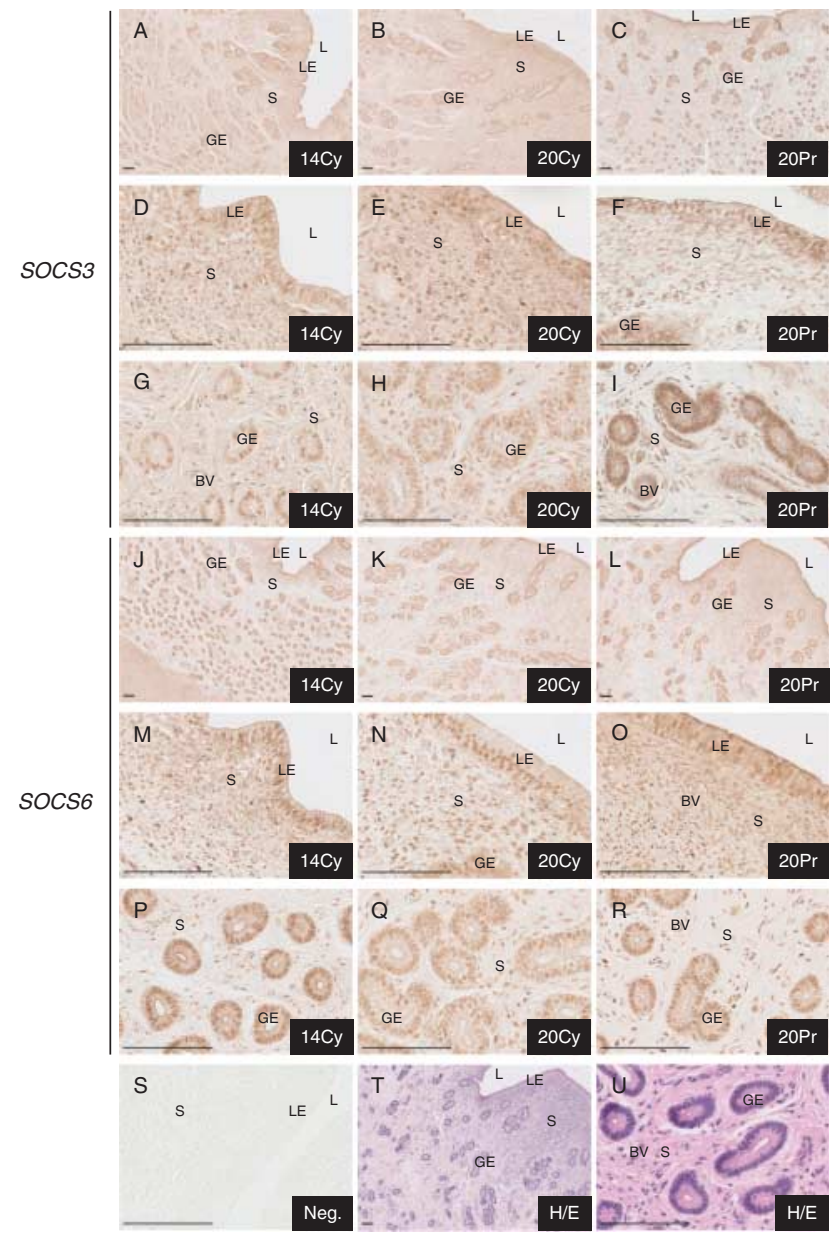

Figure 5 Cellular localisation of SOCS3 and SOCS6 protein in cyclic or pregnant bovine endometrium. Immunohistochemistry was carried out using sections cut from Charolais cows sampled at day 14 (14Cy; A, D, $\mathrm{G}, \mathrm{J}, \mathrm{M}$, and P) and day 20 of the oestrous cycle (20Cy; B, E, H, K, N, and Q) as well as day 20 (20Pr; C, F, I, L, O, and R) of pregnancy. A-I and J-R sections were respectively incubated with anti-SOCS3 and anti-SOCS6 primary antibody. Tissue samples in $\mathrm{S}$ were incubated without primary antibody as a negative control. Tissue samples in $\mathrm{T}-\mathrm{U}$ were stained with haematoxylin-eosin solution. BV, blood vessel; GE, glandular epithelium; LE, luminal epithelium; S, stroma. Scale bars $=100 \mu \mathrm{m}$. 
Table 3 Nuclear distribution of SOCS3 and SOCS6 proteins expression in bovine endometrium at day 14 (14Cy) or day 20 (20Cy) of cycle and day 20 (20Pr) of pregnancy.

\begin{tabular}{lccc}
\hline & Luminal epithelium & Stroma & Glands \\
\hline SOCS3 & & & \\
$14 \mathrm{Cy}$ & + & ++ & ++ \\
$20 \mathrm{Cy}$ & $+/++$ & $++/+++$ & ++++ \\
$20 \mathrm{Pr}$ & & & \\
SOCS6 & ++ & +++ & +++ \\
$14 \mathrm{Cy}$ & + & ++ & ++ \\
$20 \mathrm{Cy}$ & +++ & +++ & +++ \\
$20 \mathrm{Pr}$ & & + & + \\
\hline
\end{tabular}

- , no staining; + , weak staining; ++ , pronounced staining; +++ , intense staining; ++++ , very intense staining.

et al. 2012). Although the contribution/function of various endometrial factors (ligands, receptors and effectors) in the control of implantation has been unveiled based on descriptive and functional studies, few publications have focused on the regulation of SOCS genes and their biological functions in the uterus (Sandra et al. 2005, Oliveira et al. 2012). In order to provide new insights into the involvement of SOCS in endometrial physiology, a comprehensive analysis of known SOCS (CISH, SOCS1-7) gene expression profiles was carried out in bovine endometrium in order to i) establish mRNA expression patterns of the SOCS gene family during the oestrous cycle and early pregnancy, ii) determine the cellular localisation of SOCS3 and SOCS6 protein during the oestrous cycle and early pregnancy, iii) define the contribution of IFNT and of $\mathrm{P}_{4}$ in the regulation of the SOCS genes and iv) determine if endometrial SOCS mRNA levels are altered in a model of compromised pregnancy using bovine SCNT concepti.

In the bovine endometrium, all SOCS genes examined were shown to be expressed from day 5 to 20 of the oestrous cycle (present study and $\mathrm{N}$ Forde, A Vitorino Carvalho 2013, unpublished observations). The comparison of a late-luteal time point (day 16) with the period of luteolysis (proestrus: day 20) revealed higher mRNA concentrations for SOCS1, SOCS2 and SOCS3 genes but lower concentrations of SOCS5 and SOCS6 at the latter time point (day 20). A noteworthy rise in $\mathrm{CISH}$ gene transcription could also be seen between the early and late stages of the luteal phase (day 5 vs day 16 of the oestrous cycle), which was not followed by a decline at the luteolytic stage (day 20). In previously published work based on dot-blotting analyses, no change in endometrial expression of ovine CISH, SOCS1, SOCS2 and SOCS3 mRNA levels was reported during the oestrous cycle (Sandra et al. 2005). This likely reflects the lower sensitivity of the dot-blotting technique compared with the real-time PCR analyses undertaken in this study. Interestingly, microarray analysis of human endometrium (Talbi et al. 2006) has shown variations in CISH, SOCS1, SOCS2, SOCS3 and SOCS6 gene levels in the secretory phase compared with the proliferative phase. In total, these findings from both human and cattle studies indicate that endometrial SOCS1, SOCS2, SOCS3 and SOCS6 gene expression is sensitive to ovarian steroids indicative of a regulatory role. Modulation of SOCS gene expression by oestrogen or $\mathrm{P}_{4}$ has already been documented in hepatic tissues and cultured
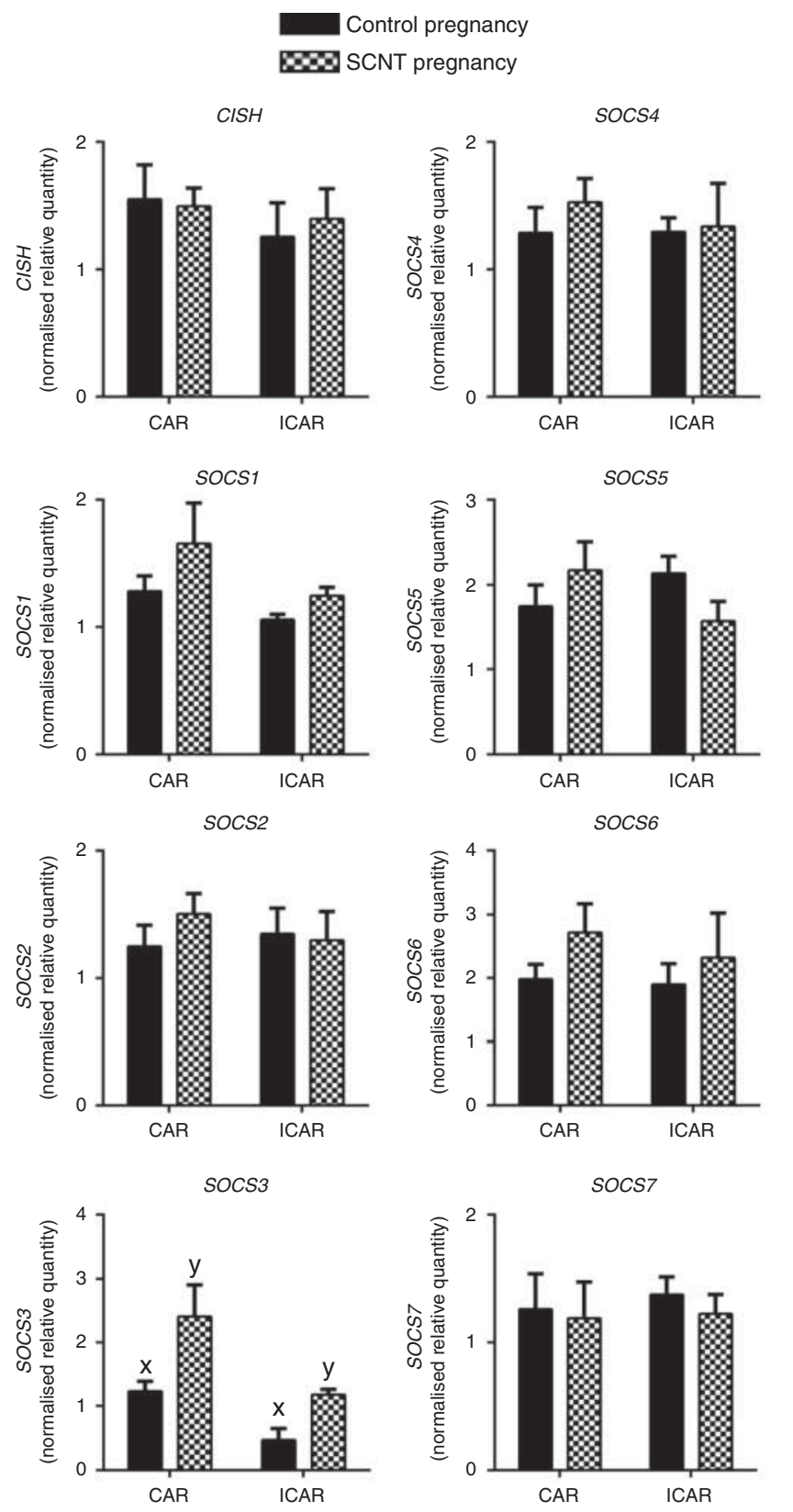

Figure 6 Endometrial SOCS gene expression in Holstein heifers carrying embryos produced by artificial insemination or transferred with SCNT produced embryos. Four females were slaughtered for each type of pregnancy at day 20 post-oestrus. Caruncular (CAR) and intercaruncular (ICAR) endometrial areas were collected separately. SOCS mRNA levels were quantified by RT-qPCR and normalised by qBasePlus on CNOT11, RPL19 and SLC3OA6. Scale bars are representative of the mean value \pm s.E.M. $x$ and $y$ letters indicate significant difference between control and SCNT pregnancy $(P<0.05)$. 
cells of breast or neuronal origin (Leong et al. 2004, Matthews et al. 2005, Steyn et al. 2008). P4-regulated SOCS factors could therefore be involved in the cross regulation of signalling pathways implicated in endometrium remodelling that takes place at the end of the oestrous cycle.

Using an in vivo experimental model of $\mathrm{P}_{4}$-supplemented heifers, we showed that $\mathrm{P}_{4}$ treatment i) led to the significant up-regulation of SOCS5, SOCS6 and SOCS7 transcript expression consistent with the decline observed at day 20 of the oestrous cycle when $\mathrm{P}_{4}$ blood level drops, and ii) did not affect CISH, SOCS1, SOCS2 and SOCS3 transcript expression. Since in non-supplemented cycles, endometrial SOCS1, SOCS2 and SOCS3 transcript levels do increase from day 16 to day 20 when luteal regression occurs, it is likely that regulatory factors other than $\mathrm{P}_{4}$ are involved. In the endometrium, during luteolysis, various parameters could account for the increased expression of these SOCS genes, including modifications of the cytokines/hormones balance (Rahman et al. 2004) and variations in type and/or number of immune cell populations such as macrophages and dendritic cells that take place in the endometrium (Cobb \& Watson 1995, Mansouri-Attia et al. 2012, Oliveira et al. 2012). Whereas the increase in CISH mRNA expression appears to be related to the acquisition of endometrial receptivity, expression changes in other SOCS genes during the oestrous cycle coincide with luteolysis and reflect a direct or an indirect consequence of declining $\mathrm{P}_{4}$ blood levels, with the identity of intermediary factors remaining to be uncovered.

In the pregnant CAR or ICAR endometrial areas compared with the cyclic tissues, distinct patterns of SOCS transcript regulation were observed. Indeed, for SOCS6, the mRNA level first rose during the maternal phase of pregnancy recognition (day 16 of pregnancy) and was further amplified at implantation (day 20 of pregnancy). Moreover, SOCS1 and SOCS3 transcript levels rose specifically at the time of implantation. This regulation of endometrial SOCS mRNA expression by the conceptus is consistent with microarray studies that listed several differentially expressed SOCS genes in the bovine pregnant endometrium compared with cyclic tissue collected at day 17 (SOCS1, Walker et al. 2010), day 18 (SOCS1, SOCS3, SOCS4, SOCS6, Bauersachs et al. 2012) and day 20 (SOCS6, Mansouri-Attia et al. 2009a) after oestrus. Interestingly, the expression patterns of CISH, SOCS1, SOCS2 and SOCS3 mRNA reported in this study are similar to the changes observed in the ovine endometrium (Sandra et al. 2005). In this species, endometrial CISH, SOCS1, SOCS2 and SOCS3 mRNA levels did not vary in ovine CAR areas during the period of maternal recognition (day 12 of pregnancy) compared with day 12 of oestrous cycle (luteal phase), but they clearly increased at day 16 of pregnancy when implantation is initiated. In cattle, at day 16 of pregnancy (maternal pregnancy recognition) compared with day 16 of the oestrous cycle (luteal phase), endometrial SOCS1, SOCS2 and SOCS3 mRNA levels were similar. However, the transcript levels of all three genes were significantly upregulated at day 20 when apposition of the extraembryonic tissues on the endometrium occurs. Altogether, global transcriptional profiles of endometrial CISH, SOCS1, SOCS2 and SOCS3 genes do not suggest critical functions for these factors during the maternal period of pregnancy recognition, but they do indicate a possible biological role for SOCS genes in driving the process of implantation in ruminants.

Although the regulation of several SOCS genes depends upon IFNT at days 16 and 20 of pregnancy, mRNA expression profiles as well as the cell localisation studies described in this study indicate that other factors participate in the regulation of endometrial SOCS gene expression. SOCS3 protein was detected in the cytoplasm and the nucleus of major cell populations that compose the endometrium including luminal epithelium, stromal cells and glandular epithelium. At implantation, when IFNT secretion declines, staining for SOCS3 was more intense in the nucleus of glandular cells, a subcellular localisation previously reported when SOCS3 is expressed at a high level in cells (Lee et al. 2008). These glandular cells secrete histotroph whose production is essential for the development and growth of the conceptus (Gray et al. 2001). In ruminants, the regulation of endometrial gland function involves $\mathrm{P}_{4}$, IFNT as well as various peptidic hormones and factors including placental lactogens and the growth hormone/ insulin growth factor (GH/IGF) family (Wathes et al. 1998, Spencer et al. 2004). During the pre-implantation period, IGF1 and IGF2 levels have been shown to increase in ovine and bovine endometrium (Geisert et al. 1991, Kirby et al. 1996, Keller et al. 1998, McCarthy et al. 2012) and IGF components are principally expressed in luminal and glandular epithelia of the bovine endometrium (McCarthy et al. 2012). SOCS proteins have been shown to modulate the JAK-STAT pathway activated by IGF and GH (Krebs \& Hilton 2001, Fujimoto \& Naka 2003). Placental lactogen (PL or chorionic somatomammotropin hormone $(\mathrm{CSH})$ ), a member of the prolactin (PRL)/GH family, is secreted by the bovine binucleate trophoblast cells from day 18 of pregnancy onwards (Kessler et al. 1991, Wooding et al. 1992) and, as for ovine CSH, its biological actions require $\mathrm{PRL}$ and $\mathrm{GH}$ receptors whose biological actions are mediated by the JAK-STAT-SOCS pathways (Biener et al. 2003, Spencer et al. 2004). Thus, from day 20 of pregnancy onwards, the increased SOCS3 in the endometrial glands could reflect the contribution of this SOCS factor in the negative control of signalling pathways stimulated by CSH and IGF ligands.

A major and unique finding of this study is that endometrial SOCS6 expression undergoes a clear increase during the maternal recognition phase and implantation. Our data demonstrate that SOCS6 is not an 
IFNT-induced nor regulated gene in vivo, confirmed by the inability of IFNT to affect SOCS6 mRNA expression at 2 or $24 \mathrm{~h}$ in vitro (this study and Vitorino Carvalho et al. (2014)). Interestingly, as for SOCS3, SOCS6 protein was detected in the cytoplasm and the nucleus of luminal epithelium, stroma cells and glandular epithelium of the endometrium. The nuclear staining of SOCS6 is consistent with published data indicating that a high level of SOCS6 expression leads to its nuclear localisation in cells (Hwang et al. 2007). Although SOCS6 regulators and its biological functions have been less investigated than for other SOCS genes, two relevant clues have recently been provided by reports showing that SOCS6 can i) potentiate signalling of the IFN type I receptor by targeting SOCS1 to induce SOCS1 proteosomal turnover (Piessevaux et al. 2006) and ii) downregulate STAT3 protein levels in HEK293T cells (Hwang et al. 2007). STAT3 is expressed in the endometrium of ruminants (Song et al. 2009) and the mRNA expression profiles of the SOCS6 and SOCSS1 genes are similar in pregnant females. This suggests that SOCS6 plays a role in the regulation of STAT3 and SOCS1 availability in the bovine endometrium. Additional studies based on the alteration of SOCS gene expression in primary cultures of endometrial cells could help in deciphering the biological roles of SOCS6 in the endometrium.

Biosensoring of embryo quality is an endometrial property that has been established in cattle (MansouriAttia et al. 2009b) and humans (Teklenburg et al. 2010). As previously reported by microarray analyses (Mansouri-Attia et al. 2009b), SCNT concepti elicit an endometrial response that, in turn, affects the progress of implantation and is associated with pregnancy failures. This study indicates an increased expression of SOCS3 mRNA levels in the endometrium of SCNT concepticarrying heifers. In transgenic mice, Socs3 overexpression leads to an embryonic lethality (as a consequence of anaemia) and to increased $\mathrm{TH} 2$ responses (reviewed in Fitzgerald et al. (2009)). This later phenotype suggests a link between SOCS3 and the deregulated immune function we have previously reported in the endometrium of SCNT pregnancies (Mansouri-Attia et al. 2009b). This increase in endometrial SOCS3 likely reflects an alteration in the quality or the type of embryonic signals emanating from SCNT concepti. Using day 18 SCNT concepti, derived from the 5538 somatic cell line (the same as the one used in our work), recent transcriptomic analyses have not focused on ligands or secreted factors that could differ with $\mathrm{Al}$ or in vitro produced (IVP) concepti (Degrelle et al. 2012). Nevertheless, these analyses did show that bovine IFNT as well as $\mathrm{CSH}$ gene expressions are identical between Al concepti and SCNT concepti derived from the 5538 cell line (Degrelle et al. 2012, Mansouri-Attia et al. 2009b; Vitorino Carvalho A, unpublished observations). Based on recent data reporting the biological functions of embryo signals other than IFNT, glucocorticoids and PGs produced by the trophectoderm and the endometrium are also part of the orchestra that regulates the expression of endometrial genes during implantation in ruminants (Dorniak et al. 2011, Majewska et al. 2012, Ulbrich et al. 2012). Compared with pregnancies obtained by IVP embryos, uterine flushings from bovine SCNT pregnancies were reported to contain lower levels of PGI2 and PGE2 due to a reduced amount of embryoand/or endometrium produced PG (reviewed by Ulbrich et al. (2012)). In rat corpus luteum and hypothalamus, PG has been shown to regulate SOCS1 and SOCS3 expression (Curlewis et al. 2002, Bonafede et al. 2011). Altogether these data suggest that the higher level of endometrial SOCS3 in SCNT pregnancy could reflect an altered production and/or metabolism of PG. In this model of compromised implantation with long-term effects, the better understanding of the events taking place in the endometrium facing cloned embryos requires a thorough characterisation of the extra-cellular signals that differ between cloned and control embryos.

Given the fact that SOCS factors not only act in a negative feedback loop to inhibit signal transduction, but also have cross-talking functions which regulate other signalling pathways, disentangling the contribution of the SOCS gene family in the regulation of endometrial function represents a challenge. Nevertheless our in vivo and in vitro models have demonstrated rapid changes in endometrial expression of SOCS3 and SOCS6 as well as SOCS1 and CISH gene levels during cycle and early pregnancy as well as in response to two major factors of the pregnancy, IFNT and $\mathrm{P}_{4}$, in cattle. Consequently, appropriate spatio-temporal expression of SOCS genes is likely necessary to fine-tune endometrial physiology during the acquisition of receptivity, maternal recognition of pregnancy and implantation. Alterations in endometrial SOCS gene expression may be detrimental for the progression of any of these steps therefore affecting global reproductive capacity of the female. Intensive efforts are currently underway to identify biomarkers of endometrial quality as well as targets for therapeutic approaches with the aim of preventing embryo implantation (contraception) or to restore the ability of the endometrium to support term pregnancy. In this context, the role of SOCS genes in the mammalian endometrium deserves further attention, particularly when functional capacity is compromised in response to environmental insults such as nutrition, stress or infections.

\section{Declaration of interest}

The authors declare that there is no conflict of interest that could be perceived as prejudicing the impartiality of the research reported. 


\section{Funding}

A Vitorino Carvalho was a $\mathrm{PhD}$ recipient from the French Ministry for Teaching and Research - Doctoral School ED419 Université Paris Sud. This work was partially supported by the European Network of Excellence 'Embryo Implantation Control' (EMBIC; LSHN-CT-2004-512040; coordinator: G Chaouat, INSERM), ANR-08-GENM-037, Science Foundation Ireland and the Higher Education Authority Irish Centre for High-End Computing (ICHEC), and the UK Biotechnology and Biological Sciences Research Council (BBSRC; BB/I017240/1).

\section{Acknowledgements}

The authors thank G Charpigny (INRA, Jouy-en-Josas, France) for supplying roIFNT, Daniel Lebourhis (UNCEIA and INRA, Jouy-en-Josas, France) for the production of SCNT embryos as well as the ICE platform (INRA, Jouy-en-Josas, France) for technical support. They express their grateful to I Hue (INRA, Jouy-en-Josas, France), postdoctoral scientists, graduate and undergraduate students as well as technical staff at UCD and INRA for assistance with sample collection. They thank the staff of INRA experimental units (Avord, France; Saint-GenèsChampanelle, France; Nouzilly, France) for animal management.

\section{References}

Aghajanova L, Altmae S, Bjuresten K, Hovatta O, Landgren BM \& StavreusEvers A 2009 Disturbances in the LIF pathway in the endometrium among women with unexplained infertility. Fertility and Sterility 91 2602-2610. (doi:10.1016/j.fertnstert.2008.04.010)

Arosh JA, Parent J, Chapdelaine P, Sirois J \& Fortier MA 2002 Expression of cyclooxygenases 1 and 2 and prostaglandin E synthase in bovine endometrial tissue during the estrous cycle. Biology of Reproduction $\mathbf{6 7}$ 161-169. (doi:10.1095/biolreprod67.1.161)

Atkinson BA, King GJ \& Amoroso EC 1984 Development of the caruncular and intercaruncular regions in the bovine endometrium. Biology of Reproduction 30 763-774. (doi:10.1095/biolreprod30.3.763)

Bauersachs S, Ulbrich SE, Reichenbach HD, Reichenbach M, Buttner M, Meyer HH, Spencer TE, Minten M, Sax G, Winter G et al. 2012 Comparison of the effects of early pregnancy with human interferon, alpha 2 (IFNA2), on gene expression in bovine endometrium. Biology of Reproduction 86 46. (doi:10.1095/biolreprod.111.094771)

Bazer FW, Wu G, Spencer TE, Johnson GA, Burghardt RC \& Bayless K 2010 Novel pathways for implantation and establishment and maintenance of pregnancy in mammals. Molecular Human Reproduction 16 135-152. (doi:10.1093/molehr/gap095)

Biener E, Martin C, Daniel N, Frank SJ, Centonze VE, Herman B, Djiane J \& Gertler A 2003 Ovine placental lactogen-induced heterodimerization of ovine growth hormone and prolactin receptors in living cells is demonstrated by fluorescence resonance energy transfer microscopy and leads to prolonged phosphorylation of signal transducer and activator of transcription (STAT)1 and STAT3. Endocrinology 144 3532-3540. (doi:10.1210/en.2003-0096)

Bonafede MM, Valdez SR, Arbocco FC, Pennacchio GE, Soaje M \& Jahn GA 2011 Effect of progesterone withdrawal on hypothalamic mechanisms related to prolactin release in late pregnant rats. Neuroendocrinology 94 148-157. (doi:10.1159/000328280)

Bullock AN, Rodriguez MC, Debreczeni JE, Songyang Z \& Knapp S 2007 Structure of the SOCS4-ElonginB/C complex reveals a distinct SOCS box interface and the molecular basis for SOCS-dependent EGFR degradation. Structure 15 1493-1504. (doi:10.1016/j.str.2007.09.016)

Carter F, Forde N, Duffy P, Wade M, Fair T, Crowe MA, Evans AC, Kenny DA, Roche JF \& Lonergan P 2008 Effect of increasing progesterone concentration from day 3 of pregnancy on subsequent embryo survival and development in beef heifers. Reproduction, Fertility, and Development 20 368-375. (doi:10.1071/RD07204)

Catalano RD, Johnson MH, Campbell EA, Charnock-Jones DS, Smith SK \& Sharkey AM 2005 Inhibition of Stat 3 activation in the endometrium prevents implantation: a nonsteroidal approach to contraception. PNAS 102 8585-8590. (doi:10.1073/pnas.0502343102)

Choi Y, Johnson GA, Burghardt RC, Berghman LR, Joyce MM, Taylor KM, Stewart MD, Bazer FW \& Spencer TE 2001 Interferon regulatory factortwo restricts expression of interferon-stimulated genes to the endometrial stroma and glandular epithelium of the ovine uterus. Biology of Reproduction 65 1038-1049. (doi:10.1095/biolreprod65.4.1038)

Cobb SP \& Watson ED 1995 Immunohistochemical study of immune cells in the bovine endometrium at different stages of the oestrous cycle. Research in Veterinary Science 59 238-241. (doi:10.1016/0034-5288 (95)90010-1)

Cronin JG, Turner ML, Goetze L, Bryant CE \& Sheldon IM 2012 Toll-like receptor 4 and MYD88-dependent signaling mechanisms of the innate immune system are essential for the response to lipopolysaccharide by epithelial and stromal cells of the bovine endometrium. Biology of Reproduction 86 51. (doi:10.1095/biolreprod.111.092718)

Curlewis JD, Tam SP, Lau P, Kusters DH, Barclay JL, Anderson ST \& Waters MJ 2002 A prostaglandin $\mathrm{f}(2 \alpha)$ analog induces suppressors of cytokine signaling-3 expression in the corpus luteum of the pregnant rat: a potential new mechanism in luteolysis. Endocrinology $\mathbf{1 4 3}$ 3984-3993. (doi:10.1210/en.2002-220344)

Degrelle SA, Campion E, Cabau C, Piumi F, Reinaud P, Richard C, Renard JP \& Hue I 2005 Molecular evidence for a critical period in mural trophoblast development in bovine blastocysts. Developmental Biology 288 448-460. (doi:10.1016/j.ydbio.2005.09.043)

Degrelle SA, Jaffrezic F, Campion E, Le Cao KA, Le Bourhis D, Richard C, Rodde N, Fleurot R, Everts RE, Lecardonnel J et al. 2012 Uncoupled embryonic and extra-embryonic tissues compromise blastocyst development after somatic cell nuclear transfer. PLoS ONE 7 e38309. (doi:10.1371/journal.pone.0038309)

Delgado-Ortega M, Marc D, Dupont J, Trapp S, Berri M \& Meurens F 2013 SOCS proteins in infectious diseases of mammals. Veterinary Immunology and Immunopathology 151 1-19. (doi:10.1016/j.vetimm.2012. 11.008)

Dimitriadis E, Stoikos C, Tan YL \& Salamonsen LA 2006 Interleukin 11 signaling components signal transducer and activator of transcription 3 (STAT3) and suppressor of cytokine signaling 3 (SOCS3) regulate human endometrial stromal cell differentiation. Endocrinology 147 3809-3817. (doi:10.1210/en.2006-0264)

Dorniak P, Bazer FW \& Spencer TE 2011 Prostaglandins regulate conceptus elongation and mediate effects of interferon tau on the ovine uterine endometrium. Biology of Reproduction 84 1119-1127. (doi:10.1095/ biolreprod.110.089979)

Ealy AD \& Yang QE 2009 Control of interferon-tau expression during early pregnancy in ruminants. American Journal of Reproductive Immunology 61 95-106. (doi:10.1111/j.1600-0897.2008.00673.x)

Endo TA, Masuhara M, Yokouchi M, Suzuki R, Sakamoto H, Mitsui K, Matsumoto A, Tanimura S, Ohtsubo M, Misawa H et al. 1997 A new protein containing an $\mathrm{SH} 2$ domain that inhibits JAK kinases. Nature $\mathbf{3 8 7}$ 921-924. (doi:10.1038/43213)

Eozenou C, Vitorino Carvalho A, Forde N, Giraud-Delville C, Gall L, Lonergan P, Auguste A, Charpigny G, Richard C, Pannetier M et al. 2012 FOXL2 is regulated during the bovine estrous cycle and its expression in the endometrium is independent of conceptus-derived interferon tau. Biology of Reproduction 87 32. (doi:10.1095/biolreprod.112.101584)

Fitzgerald JS, Toth B, Jeschke U, Schleussner E \& Markert UR 2009 Knocking off the suppressors of cytokine signaling (SOCS): their roles in mammalian pregnancy. Journal of Reproductive Immunology 83 117-123. (doi:10.1016/j.jri.2009.07.010)

Forde N, Carter F, Spencer TE, Bazer FW, Sandra O, Mansouri-Attia N, Okumu LA, McGettigan PA, Mehta JP, McBride R et al. $2011 b$ Conceptus-induced changes in the endometrial transcriptome: how soon does the cow know she is pregnant? Biology of Reproduction $\mathbf{8 5}$ 144-156. (doi:10.1095/biolreprod.110.090019)

Forde N, Beltman ME, Duffy GB, Duffy P, Mehta JP, $\mathrm{O}^{\prime}$ Gaora P, Roche JF, Lonergan P \& Crowe MA 2011a Changes in the endometrial 
transcriptome during the bovine estrous cycle: effect of low circulating progesterone and consequences for conceptus elongation. Biology of Reproduction 84 266-278. (doi:10.1095/biolreprod.110.085910)

Forde N, Duffy GB, McGettigan PA, Browne JA, Mehta JP, Kelly AK, Mansouri-Attia N, Sandra O, Loftus BJ, Crowe MA et al. 2012 Evidence for an early endometrial response to pregnancy in cattle: both dependent upon and independent of interferon tau. Physiological Genomics 44 799-810. (doi:10.1152/physiolgenomics.00067.2012)

Fujimoto M \& Naka T 2003 Regulation of cytokine signaling by SOCS family molecules. Trends in Immunology 24 659-666. (doi:10.1016/j.it. 2003.10.008)

Geisert RD, Lee CY, Simmen FA, Zavy MT, Fliss AE, Bazer FW \& Simmen RC 1991 Expression of messenger RNAs encoding insulin-like growth factor-I, -II, and insulin-like growth factor binding protein-2 in bovine endometrium during the estrous cycle and early pregnancy. Biology of Reproduction 45 975-983. (doi:10.1095/biolreprod45.6.975)

Gray CA, Taylor KM, Ramsey WS, Hill JR, Bazer FW, Bartol FF \& Spencer TE 2001 Endometrial glands are required for preimplantation conceptus elongation and survival. Biology of Reproduction 64 1608-1613. (doi:10.1095/biolreprod64.6.1608)

Gray CA, Burghardt RC, Johnson GA, Bazer FW \& Spencer TE 2002 Evidence that absence of endometrial gland secretions in uterine gland knockout ewes compromises conceptus survival and elongation. Reproduction 124 289-300. (doi:10.1530/rep.0.1240289)

Gray CA, Abbey CA, Beremand PD, Choi Y, Farmer JL, Adelson DL, Thomas TL, Bazer FW \& Spencer TE 2006 Identification of endometrial genes regulated by early pregnancy, progesterone, and interferon tau in the ovine uterus. Biology of Reproduction 74 383-394. (doi:10.1095/ biolreprod.105.046656)

Guillomot M 1995 Cellular interactions during implantation in domestic ruminants. Journal of Reproduction and Fertility Supplement 49 39-51.

Hansen PJ 2011 The immunology of early pregnancy in farm animals. Reproduction in Domestic Animals = Zuchthygiene 46 (Suppl 3) 18-30.

Hilton DJ, Richardson RT, Alexander WS, Viney EM, Willson TA, Sprigg NS, Starr R, Nicholson SE, Metcalf D \& Nicola NA 1998 Twenty proteins containing a C-terminal SOCS box form five structural classes. PNAS 95 114-119. (doi:10.1073/pnas.95.1.114)

Hwang MN, Min CH, Kim HS, Lee H, Yoon KA, Park SY, Lee ES \& Yoon S 2007 The nuclear localization of SOCS6 requires the $\mathrm{N}$-terminal region and negatively regulates Stat3 protein levels. Biochemical and Biophysical Research Communications 360 333-338. (doi:10.1016/ j.bbrc.2007.06.062)

Joyce MM, Burghardt RC, Geisert RD, Burghardt JR, Hooper RN, Ross JW, Ashworth MD \& Johnson GA 2007 Pig conceptuses secrete estrogen and interferons to differentially regulate uterine STAT1 in a temporal and cell type-specific manner. Endocrinology 148 4420-4431. (doi:10.1210/en. 2007-0505)

Keller ML, Roberts AJ \& Seidel GE Jr 1998 Characterization of insulin-like growth factor-binding proteins in the uterus and conceptus during early conceptus elongation in cattle. Biology of Reproduction 59 632-642. (doi:10.1095/biolreprod59.3.632)

Kessler MA, Duello TM \& Schuler LA 1991 Expression of prolactinrelated hormones in the early bovine conceptus, and potential for paracrine effect on the endometrium. Endocrinology 129 1885-1895. (doi:10.1210/endo-129-4-1885)

Kile BT, Schulman BA, Alexander WS, Nicola NA, Martin HM \& Hilton DJ 2002 The SOCS box: a tale of destruction and degradation. Trends in Biochemical Sciences 27 235-241. (doi:10.1016/S0968-0004(02) 02085-6)

Kim S, Choi Y, Bazer FW \& Spencer TE 2003 Identification of genes in the ovine endometrium regulated by interferon tau independent of signal transducer and activator of transcription 1. Endocrinology $\mathbf{1 4 4}$ 5203-5214. (doi:10.1210/en.2003-0665)

Kirby CJ, Thatcher WW, Collier RJ, Simmen FA \& Lucy MC 1996 Effects of growth hormone and pregnancy on expression of growth hormone receptor, insulin-like growth factor-I, and insulin-like growth factor binding protein-2 and -3 genes in bovine uterus, ovary, and oviduct. Biology of Reproduction 55 996-1002. (doi:10.1095/biolreprod55. 5.996)

Krebs DL \& Hilton DJ 2001 SOCS proteins: negative regulators of cytokine signaling. Stem Cells 19 378-387. (doi:10.1634/stemcells.19-5-378)
Lee KH, Moon KJ, Kim HS, Yoo BC, Park S, Lee H, Kwon S, Lee ES \& Yoon S 2008 Increased cytoplasmic levels of CIS, SOCS1, SOCS2, or SOCS3 are required for nuclear translocation. FEBS Letters 582 2319-2324. (doi:10.1016/j.febslet.2008.05.039)

Leong GM, Moverare S, Brce J, Doyle N, Sjogren K, Dahlman-Wright K, Gustafsson JA, Ho KK, Ohlsson C \& Leung KC 2004 Estrogen up-regulates hepatic expression of suppressors of cytokine signaling-2 and -3 in vivo and in vitro. Endocrinology 145 5525-5531. (doi:10.1210/ en.2004-0061)

Maj T \& Chelmonska-Soyta A 2007 Pleiotropy and redundancy of STAT proteins in early pregnancy. Reproduction in Domestic Animals = Zuchthygiene 42 343-353. (doi:10.1111/j.1439-0531.2006.00787.x)

Majewska M, Lee HY, Tasaki Y, Acosta TJ, Szostek AZ, Siemieniuch M, Okuda K \& Skarzynski DJ 2012 Is cortisol a modulator of interferon tau action in the endometrium during early pregnancy in cattle? Journal of Reproductive Immunology 93 82-93. (doi:10.1016/j.jri.2012.01.004)

Mansouri-Attia N, Aubert J, Reinaud P, Giraud-Delville C, Taghouti G, Galio L, Everts RE, Degrelle S, Richard C, Hue I et al. 2009a Gene expression profiles of bovine caruncular and intercaruncular endometrium at implantation. Physiological Genomics 39 14-27. (doi:10.1152/ physiolgenomics.90404.2008)

Mansouri-Attia N, Sandra O, Aubert J, Degrelle S, Everts RE, GiraudDelville C, Heyman Y, Galio L, Hue I, Yang X et al. 2009b Endometrium as an early sensor of in vitro embryo manipulation technologies. PNAS 106 5687-5692. (doi:10.1073/pnas.0812722106)

Mansouri-Attia N, Oliveira LJ, Forde N, Fahey AG, Browne JA, Roche JF, Sandra O, Reinaud P, Lonergan P \& Fair T 2012 Pivotal role for monocytes/macrophages and dendritic cells in maternal immune response to the developing embryo in cattle. Biology of Reproduction 87 123. (doi:10.1095/biolreprod.112.101121)

Matthews J, Almlof T, Kietz S, Leers J \& Gustafsson JA 2005 Estrogen receptor-alpha regulates SOCS-3 expression in human breast cancer cells. Biochemical and Biophysical Research Communications 335 168-174. (doi:10.1016/j.bbrc.2005.07.057)

McCarthy SD, Roche JF \& Forde N 2012 Temporal changes in endometrial gene expression and protein localization of members of the IGF family in cattle: effects of progesterone and pregnancy. Physiological Genomics 44 130-140. (doi:10.1152/physiolgenomics.00106.2011)

Naka T, Narazaki M, Hirata M, Matsumoto T, Minamoto S, Aono A, Nishimoto N, Kajita T, Taga T, Yoshizaki K et al. 1997 Structure and function of a new STAT-induced STAT inhibitor. Nature 387 924-929. (doi:10.1038/43219)

Oliveira LJ, Barreto RS, Perecin F, Mansouri-Attia N, Pereira FT \& Meirelles FV 2012 Modulation of maternal immune system during pregnancy in the cow. Reproduction in Domestic Animals = Zuchthygiene 47 (Suppl 4) 384-393. (doi:10.1111/j.1439-0531.2012.02102.x)

Piessevaux J, Lavens D, Montoye T, Wauman J, Catteeuw D, Vandekerckhove J, Belsham D, Peelman F \& Tavernier J 2006 Functional cross-modulation between SOCS proteins can stimulate cytokine signaling. Journal of Biological Chemistry 281 32953-32966. (doi:10.1074/ jbc.M600776200)

Rahman AN, Snibson KJ, Lee CS \& Meeusen EN 2004 Effects of implantation and early pregnancy on the expression of cytokines and vascular surface molecules in the sheep endometrium. Journal of Reproductive Immunology 64 45-58. (doi:10.1016/j.jri.2004.08.008)

Rico-Bautista E, Flores-Morales A \& Fernandez-Perez L 2006 Suppressor of cytokine signaling (SOCS) 2, a protein with multiple functions. Cytokine \& Growth Factor Reviews 17 431-439. (doi:10.1016/j.cytogfr.2006. 09.008)

Roberts RM 2007 Interferon-tau, a type 1 interferon involved in maternal recognition of pregnancy. Cytokine \& Growth Factor Reviews 18 403-408. (doi:10.1016/j.cytogfr.2007.06.010)

Salamonsen LA, Nie G, Hannan NJ \& Dimitriadis E 2009 Society for Reproductive Biology Founders' Lecture 2009, preparing fertile soil: the importance of endometrial receptivity. Reproduction, Fertility, and Development 21 923-934. (doi:10.1071/RD09145)

Sandra O, Bataillon I, Roux P, Martal J, Charpigny G, Reinaud P, Bolifraud P, Germain G \& Al-Gubory KH 2005 Suppressor of cytokine signalling (SOCS) genes are expressed in the endometrium and regulated by conceptus signals during early pregnancy in the ewe. Journal of Molecular Endocrinology 34 637-644. (doi:10.1677/jme.1.01667) 
Sandra O, Mansouri-Attia N \& Lea RG 2011 Novel aspects of endometrial function: a biological sensor of embryo quality and driver of pregnancy success. Reproduction, Fertility, and Development 24 68-79. (doi:10.1071/RD11908)

Song G, Satterfield MC, Kim J, Bazer FW \& Spencer TE 2009 Progesterone and interferon tau regulate leukemia inhibitory factor receptor and IL6ST in the ovine uterus during early pregnancy. Reproduction 137 553-565. (doi:10.1530/REP-08-0437)

Spencer TE, Johnson GA, Burghardt RC \& Bazer FW 2004 Progesterone and placental hormone actions on the uterus: insights from domestic animals. Biology of Reproduction 71 2-10. (doi:10.1095/biolreprod.103.024133)

Spencer TE, Johnson GA, Bazer FW, Burghardt RC \& Palmarini M 2007 Pregnancy recognition and conceptus implantation in domestic ruminants: roles of progesterone, interferons and endogenous retroviruses. Reproduction, Fertility, and Development 19 65-78. (doi:10.1071/ RD06102)

Spencer TE, Sandra O \& Wolf E 2008 Genes involved in conceptusendometrial interactions in ruminants: insights from reductionism and thoughts on holistic approaches. Reproduction 135 165-179. (doi:10.1530/REP-07-0327)

Starr R, Willson TA, Viney EM, Murray LJ, Rayner JR, Jenkins BJ, Gonda TJ, Alexander WS, Metcalf D, Nicola NA et al. 1997 A family of cytokineinducible inhibitors of signalling. Nature 387 917-921. (doi:10.1038/ 43206)

Steyn FJ, Anderson GM \& Grattan DR 2008 Hormonal regulation of suppressors of cytokine signaling (SOCS) messenger ribonucleic acid in the arcuate nucleus during late pregnancy. Endocrinology 149 3206-3214. (doi:10.1210/en.2007-1623)

Talbi S, Hamilton AE, Vo KC, Tulac S, Overgaard MT, Dosiou C, Le Shay N, Nezhat CN, Kempson R, Lessey BA et al. 2006 Molecular phenotyping of human endometrium distinguishes menstrual cycle phases and underlying biological processes in normo-ovulatory women. Endocrinology 147 1097-1121. (doi:10.1210/en.2005-1076)

Teklenburg G, Salker M, Molokhia M, Lavery S, Trew G, Aojanepong T, Mardon HJ, Lokugamage AU, Rai R, Landles C et al. 2010 Natural selection of human embryos: decidualizing endometrial stromal cells serve as sensors of embryo quality upon implantation. PLOS ONE 5 e10258. (doi:10.1371/journal.pone.0010258)

Ulbrich SE, Wolf E \& Bauersachs S 2012 Hosting the preimplantation embryo: potentials and limitations of different approaches for analysing embryo-endometrium interactions in cattle. Reproduction, Fertility, and Development 25 62-70. (doi:10.1071/RD12279)
Vitorino Carvalho A, Eozenou C, Healey GD, Forde N, Reinaud P, Chebrout M, Gall L, Rodde R, Lesage Padilla A, Giraud Delville C et al. 2014 Analysis of STAT1 expression and biological activity reveals interferon-tau-dependent STAT1-regulated SOCS genes in the bovine endometrium. Reproduction, Fertility, and Development. In press. (doi:10.1071/RD14034)

Walker CG, Meier S, Littlejohn MD, Lehnert K, Roche JR \& Mitchell MD 2010 Modulation of the maternal immune system by the preimplantation embryo. BMC Genomics 11 474. (doi:10.1186/14712164-11-474)

Wang H \& Dey SK 2006 Roadmap to embryo implantation: clues from mouse models. Nature Reviews. Genetics 7 185-199. (doi:10.1038/ nrg1808)

Wathes DC, Reynolds TS, Robinson RS \& Stevenson KR 1998 Role of the insulin-like growth factor system in uterine function and placental development in ruminants. Journal of Dairy Science 81 1778-1789. (doi:10.3168/jds.S0022-0302(98)75747-9)

Weimar CH, Kavelaars A, Brosens JJ, Gellersen B, de Vreeden-Elbertse JM, Heijnen CJ \& Macklon NS 2012 Endometrial stromal cells of women with recurrent miscarriage fail to discriminate between high- and lowquality human embryos. PLOS ONE 7 e41424. (doi:10.1371/journal. pone.0041424)

Wooding FB, Morgan G, Forsyth IA, Butcher G, Hutchings A, Billingsley SA \& Gluckman PD 1992 Light and electron microscopic studies of cellular localization of oPL with monoclonal and polyclonal antibodies. Journal of Histochemistry and Cytochemistry 40 1001-1009. (doi:10.1177/40.7.1607634)

Yoshimura A, Ohkubo T, Kiguchi T, Jenkins NA, Gilbert DJ, Copeland NG, Hara T \& Miyajima A 1995 A novel cytokine-inducible gene CIS encodes an $\mathrm{SH}$-containing protein that binds to tyrosine-phosphorylated interleukin 3 and erythropoietin receptors. EMBO Journal 14 2816-2826.

Yoshimura A, Naka T \& Kubo M 2007 SOCS proteins, cytokine signalling and immune regulation. Nature Reviews. Immunology 7 454-465. (doi:10.1038/nri2093)

Received 4 August 2014

First decision 27 August 2014

Revised manuscript received 28 August 2014

Accepted 2 September 2014 